\title{
Antifungal Activity of Croton aromaticus L. in vitro, Against Post-Harvest Fungal Pathogens Isolated from Tropical Fruits
}

\author{
S. A. D. T. L. Wijesundara, B. T. S. D. P. Kannangara ${ }^{1}$ and K. Abeywickrama \\ Received: $3^{\text {rd }}$ September 2015 / Accepted: $11^{\text {th }}$ November 2015
}

\begin{abstract}
Synthetic fungicides are widely used in controlling postharvest diseases of fruits worldwide. The interest offinding natural bioactive components has increased due to the harmful effects of synthetic fungicides on environment and health. Present study was an attempt to evaluate the antifungal activity of ethanolic extract of Croton aromaticus leaves in vitro, against mycelial growth and spore germination of postharvest fungal pathogens isolated from banana (Colletotrichum musae, Lasiodiplodia theobromae), papaya (Colletotrichum gleosporioides, L. theobromae) and mango (Alternaria alternata, Pestalotiopsis mangiferae, L. theobromae), and to analyze phytochemicals of the extract qualitatively. Inhibitory effect of the ethanolic extract was investigated by well diffusion method with different concentrations (1, 5, 10, 30, 50, 100, 200 and $300 \mathrm{mg} \mathrm{ml}^{-1}$ ) along with positive control (Captan) and negative control (DMSO). Significant inhibitory effects $(P<0.05)$ were exhibited by the extract against $C$. musae, $P$. mangiferae, A. alternata and $C$. gleosporioides except $L$. theobromae. The lowest minimum inhibitory concentration (MIC) value of the leaf extract $\left(5 \mathrm{mg} \mathrm{ml}^{-1}\right)$ was observed for C. gleosporioides and P. mangiferae. Qualitative phytochemical analysis revealed the presence of alkaloids, terpenoids, quinones, phytosterols and flavonoids in leaf extract of the plant. Thin layer chromatographic (TLC) assay revealed the presence of four bioactive compounds with $R f$ values of $0.551,0.672,0.810$ and 0.913 .
\end{abstract}

Keywords: antifungal assay, croton aromaticus, postharvest diseases.

\section{INTRODUCTION}

Increasing demand for nutritional foods is paralleled by a more pronounced request for natural ingredients and fresh foods such as fruits and vegetables. Fresh fruits are perishable commodities that can be easily invaded by microbial pathogens, which lead to very high postharvest losses reducing their commercial and nutritional values (Mari et al., 2014). Compared to other microbial pathogens, fungi cause the greatest impact with regard to post harvest diseases. Shelf life of economically important tropical fruits such as banana, papaya and mango, is greatly affected by post harvest diseases such as crown rot, anthracnose and stem end rot caused by fungal pathogens (Adme et al., 2013).

Stem-end rot is a common disease of mango ( $M$. indica) caused by several fungi including L. theobromae and P. mangiferae. (Meer et al., 2013) A. alternata cause black spots and side rot of mango which makes them unmarketable (Mansour et al., 2006). Anthracnose and stemend rot cause considerable post harvest loss of papaya (Carica papaya), which is caused by $C$. gleosporioides and the association of L. theobromae and Phomopsis caricaepapayae, respectively (Abeywickrama et al., 
2012). Crown rot of banana (Musa) is caused by a complex of fungi including Fusarium proliferatum, L. theobromae, C. musae and Verticillium theobromae (Anthony et al., 2004).

Chemical control using synthetic chemical fungicides is still the most common method of controlling postharvest diseases of fruits. Fungicides such as Benomyl, which has carcinogenic effects are used to control post harvest diseases of banana in some countries (Ranasinghe etal.,2003). Therefore, the attention on reducing the use of synthetic fungicides is becoming popular due to their harmful toxic effects on humans and environment. Previous extensive research conducted at University of Kelaniya have revealed the efficacy of essential oils on ovipositional deterrence and progeny production deterrence in stored products pests such as cowpea bruchid (Paranagama et al., 2003). Essential oils are natural volatile substances found in a variety of odoriferous plants. Investigations on plant derivatives with known antifungal properties have revealed possible alternatives to synthetic fungicides (Singh et al., 2012). Cinnamon (Cinnamomum zeylanicum) leaf, bark and clove (Syzygium aromaticum) oils have exhibited antifungal activity against crown rot and anthracnose pathogens of banana (Ranasinghe et al., 2002). Similarly Anthony et al., (2004) reported that the Ocimum basilicum and Cymbopogon nardus oils exhibited bioactivity against $C$. musae and Fusarium proliferatum both isolated from Embul variety banana. Ethanol, methanol and chloroform extracts of Piper sarmentosum leaves were found to be highly effective in inhibiting both mycelial growth and spore germination of $C$. gloeosporioides (Bussaman et al., 2012).

Croton is a genus belonging to family Euphorbiaceae, widespread in tropical regions. Croton aromaticus (Sin: Kappettiya) has found to be used in traditional agriculture and ethnomedicine (Bandara et al., 1990). Several species of Croton is being used medicinally as a treatment for fever, dysentery, inflammation and malaria. The genus croton is found to be rich in bioactive compounds such as diterpenes and alkaloids (Salatino et al., 2007). The leaves of Croton lacciferus are used for manuring paddy fields as they are thought to control certain soil-borne pests and diseases in Sri Lanka (Jayaweera and Senaratna, 2006). Secondary metabolites such as saponins, steroids and tannins were found to be present in ethanolic extract of Croton polyandrus which have shown antifungal activity against Candida albicans (Fernandes et al., 2013). Some croton species have displayed larvicidal and insecticidal activities. As examples, compounds isolated from the chloroform extract of roots of $C$. aromaticus has demonstrated insecticidal activity against groundnut aphid (Bandara et al., 1990). Furthermore, crude and solvent extracts of Croton caudatus fruits have shown synergistic effect against Culex quinquefasciatus larvae (Singha et al., 2011).

Hence, the present study aims to investigate on the in vitro antifungal effect of $C$. aromaticus against post harvest fungal pathogens such as C. musae, L. theobromae, C. gleosporioides, $A$. alternata, and $P$. mangiferae which were isolated from banana (Musa), papaya ( $C$. papaya) and mango (M. indica) and to identify the phytochemical constituents of the ethanolic extract of leaves of $C$. aromaticus.

\section{MATERIALS AND METHODS}

\section{Plant material and extraction}

Leaves of $C$. aromaticus were collected from three different areas in Kalutara district in Sri Lanka. Dry specimens of the plant samples were prepared according to herbarium techniques and the identity of specimens were confirmed by comparing them with the specimens available at the National Herbarium, Peradeniya, Sri Lanka. Fresh leaf samples were thoroughly washed using tap water. Then they were air - 
dried at room temperature $\left(28 \pm 2{ }^{\circ} \mathrm{C}\right)$ for several weeks and ground into a uniform powder using a grinder (LM2421, Group SEB, France).

The ethanolic extract was prepared from the dried powdered material of leaves (100 g), macerated with $95 \%$ ethanol $(500 \mathrm{ml})$ for 72 hours at room temperature $\left(28 \pm 2{ }^{\circ} \mathrm{C}\right)$. Extract was then filtered through Whatman No.1 filter paper. Filtrate was concentrated and evaporated to dryness under vacuum at $40{ }^{\circ} \mathrm{C}$ using a rotary evaporator (CH-9230, Laboratoriums Technik AG, Swiss). The extract was then stored at $4^{\circ} \mathrm{C}$ until further use (Britto et al., 2012).

\section{Preparations of plant extract dilutions}

Aliquots in mg 1.0, 5.0, 10.0, 30.0, 50.0, 100.0, 200.0 and 300.0 of ethanolic extract of leaves of C. aromaticus were dissolved in sterile dimethyl sulfoxide (DMSO) to obtain dilutions of $1 \mathrm{mg}$ $\mathrm{ml}^{-1}$ upto $300 \mathrm{mg} \mathrm{ml}^{-1}$ (Amjad et al., 2012).

\section{Isolation and identification of post harvest fungal pathogens}

Banana, mango and papaya fruits were collected from markets in Kelaniya. Diseased fruit tissues $\left(4 \mathrm{~mm}^{2}\right)$ were cut from margins of anthracnose lesions, crown rot surface and side rots under aseptic conditions. Then tissues were surface sterilized by soaking in freshly prepared $\mathrm{NaOCl}(3 \% \mathrm{w} / \mathrm{v})$ for three minutes. After three serial washings in sterile distilled water, fruit tissues were placed on potato dextrose agar (PDA) and incubated at room temperature $\left(28 \pm 2{ }^{\circ} \mathrm{C}\right)$. Fungal colonies that appeared were sub cultured in order to obtain pure cultures (Anthony et al., 2004). The fungal pathogens were identified by studying their morphological and microscopic characteristics using the sticky tape method (Felgel, 1980), identification keys (Abeywickrama, 2006) and also by comparing them with culture collection, available in the Department of Botany, University of Kelaniya.

\section{Determination of antifungal activity of $C$. aromaticus leaf extract by agar well diffusion method}

\section{Inhibition of mycelial growth :}

Sterilized PDA $(20 \mathrm{ml})$ was poured into each sterile petri dish and allowed to solidify. Four wells were made in each plate using a sterile cork borer with a diameter of $7.0 \mathrm{~mm}$. Subsequently, $5.0 \mathrm{~mm}$ diameter plugs from seven day old pure cultures of pathogenic fungus $[L$. theobromae (Banana, Mango and papaya), A. alternata and P. mangiferae (Mango), C. gleosporioides (Papaya) and C. musae (Banana)] was obtained using a sterile cork borer and placed in the middle of each plate separately. The test solution $(300 \mu \mathrm{l})$ at different concentrations $\left(1 \mathrm{mg} \mathrm{ml}^{-1}\right.$, $5 \mathrm{mg} \mathrm{ml}^{-1}, 10 \mathrm{mg} \mathrm{ml}^{-1}, 30 \mathrm{mg} \mathrm{ml}^{-1}, 50 \mathrm{mg} \mathrm{ml}^{-}$ 1, $100 \mathrm{mg} \mathrm{ml}^{-1}, 200 \mathrm{mg} \mathrm{ml}^{-1}$ and $300 \mathrm{mg} \mathrm{ml}^{-1}$ ) was poured into wells of each plate separately using a sterile micro pipette. The plates were incubated at room temperature $\left(28 \pm 2{ }^{\circ} \mathrm{C}\right)$ for seven days. The zone of inhibition was recorded by measuring the diameter of each inhibition zone (in $\mathrm{cm}$ ) including the well diameter. The readings were taken in three different fixed directions and the average values were tabulated. Captan, a commercially available fungicide was used as the compatible positive control with $1 \mathrm{mg} \mathrm{ml}^{-1}$ up to $300 \mathrm{mg} \mathrm{ml}^{-1}$ concentrations. Sterile DMSO (300 $\mu \mathrm{l})$ was used as the negative control. Triplicate plates were maintained for each treatment (Amjad et al., 2012).

\section{Inhibition of spore germination :}

Conidia were harvested from seven day-old pure cultures of fungal pathogens (C. musae, A. alternata, $P$. mangiferae and $C$. gleosporioides) by adding $10 \mathrm{ml}$ of sterilized distilled water into the petri dishes and gently rubbing the sporulating mycelial mat with a sterile bent glass rod. These conidial suspensions were filtered through a muslin cloth to remove mycelial 
fragments. The approximate number of conidia was determined using a hemocytometer (Levy Ultra Plane, C. A. Hausser \& Sons, U.S.A.) and the concentration of conidia were adjusted to $10^{5}$ conidia $\mathrm{ml}^{-1}$ (Paranagama et al., 2007).

Sterilized PDA $(20 \mathrm{ml})$ was poured into sterile petri dishes and allowed to solidify. Conidial suspension $(0.1 \mathrm{ml})$ was seeded on the entire surface of the agar by spreading with a sterile glass spreader. Four wells were made in each plate using a sterile cork borer with a diameter of $7.0 \mathrm{~mm}$. Subsequently, the test solution $(300$ $\mu \mathrm{l})$ at different concentrations $\left(1 \mathrm{mg} \mathrm{ml}^{-1}\right.$ up to $300 \mathrm{mg} \mathrm{ml}^{-1}$ ) of ethanolic extract was poured into the wells of each plate separately using a sterile micro pipette. Captan, was used as the positive control with similar concentrations as mentioned above. Sterile DMSO $(300 \mu \mathrm{l})$ was used as the negative control. The plates were incubated at room temperature $\left(28 \pm 2{ }^{\circ} \mathrm{C}\right)$ for seven days. The zone of inhibition in each plate was recorded by measuring the diameter of the inhibition zone (in $\mathrm{cm}$ ) including the well diameter. The readings were taken in three different fixed directions and the average values were tabulated. Triplicate plates were maintained for each experiment (Amjad et al., 2012).

\section{Determination of minimum concentrations (MIC)}

By comparing the different concentrations of C. aromaticus leaf extract which gave clear zones of inhibition, the minimum inhibitory concentration that required to inhibit mycelial growth and spore germination was determined. The lowest concentration of the extract that inhibited the visible growth of a particular fungus was selected as the MIC (Britto et al., 2012).

\section{Phytochemical screening}

\section{Identifying compounds by thin-layer chromatography :}

Ethanolic extract of $C$. aromaticus leaves was dissolved in dichloro methane. Small amounts $(5 \mu \mathrm{l})$ of the mixture was spotted on a $20 \mathrm{~cm}$ x $10 \mathrm{~cm}$ precoated thin layer chromatographic (silica gel $60-\mathrm{F}-254)$ plates $(0.5 \mathrm{~mm}$ thickness, Merck, Germany). They were developed in the solvent system dichloro methane: methanol (99 : $1 \mathrm{v} / \mathrm{v}$ ), for about 1 hour (Fardin and Young, 2015). Developed chromatogram was observed under ultra violet (UV) light and subsequently under visible light after spraying p-anisaldehyde reagent and heating to $105{ }^{\circ} \mathrm{C}$. The retention factor ( $\mathrm{Rf})$ values of all the spots were determined.

\section{Identifying compounds by chemical test:}

One gram of the ethanolic extract of $C$. aromaticus leaves was dissolved in $100 \mathrm{ml}$ of ethanol to obtain a stock solution (Rajan et al., 2011). The ethanolic extract was tested for the presence of bioactive compounds such as alkaloids, saponin, terpenoids, quinones, phenol, tannin (Ugochukwu et al., 2013), phyto sterols (Rajan et al., 2011) and flavonoids (Vishwakarma et al., 2014) by following standard methods.

Test for Alkaloids (Wagner's reagent) - A fraction of the extract was treated with 3-5 drops of Wagner's reagent (1.27 $\mathrm{g}$ of iodine and $2 \mathrm{~g}$ of potassium iodide in $100 \mathrm{ml}$ of water) and observed for the formation of reddish brown precipitate.

Test for Saponins (Foam test) - Two mililitre of the extract was added to $6 \mathrm{ml}$ of water in a test tube. The mixture was then shaken vigorously and observed for the formation of persistent foam that confirms the presence of saponins.

Test for Terpenoids (Salkowki's test) - One mililitre of chloroform was added to $2 \mathrm{ml}$ of each extract followed by a few drops of concentrated sulphuric acid. A reddish brown precipitate produced immediately indicated the presence of terpenoids.

Test for Quinones - A small fraction of the extract was treated with concentrated HCL 
and then observed for the formation of yellow precipitate (or colouration).

Test for Phenols (Ferric chloride test) - A fraction of the extract was treated with aqueous $5 \%$ ferric chloride and observed for the formation of deep blue or black colour.

Test for Tannins - Two militre of extract was treated with $10 \%$ alcoholic ferric chloride solution and observed for the formation of blue or greenish colour solution.

Test for Phyto Sterols - Small Fraction of the extract was dissolved in $5 \mathrm{ml}$ of chloroform. Few drops of concentrated sulphuric acid were added to $1 \mathrm{ml}$ of prepared chloroform solution. Formation of brown ring indicates the presence of phyto sterols.

Test for Flavonoids - One mililitre of $2 \mathrm{~mol} \mathrm{l}^{-1}$ $\mathrm{NaOH}$ was added to $1 \mathrm{ml}$ of the leaf extract. Appearance of yellow colour indicates the presence of flavonoids.

\section{Statistical analysis}

Diameters of the inhibitory zones obtained with ethanolic extract, captan and DMSO were subjected to one-way ANOVA and the mean values were compared using Tukey's multiple comparison test. Statistical analysis was done using the MINITAB 16 statistical package. The level of $\mathrm{P}<0.05$ was considered statistically significant.

\section{RESULTS AND DISCUSSION}

\section{Isolation and identification of post harvest fungal pathogens}

Causative agents were identified as $C$. musae and $L$. theobromae from banana, A. alternata, $L$. theobromae and P. mangiferae from mango, $C$. gleosporioides and $L$. theobromae from papaya. All isolated pathogens were subjected to antifungal assays.

\section{Antifungal activity of $C$. aromaticus leaf extract by agar well diffusion method}

According to the results, the mycelial growth (Table 01) and the spore germination (Table 02) of C. musae, A. alternata, C. gleosporioides and $P$. mangiferae were significantly $(\mathrm{P}<$ 0.05 ) inhibited by the ethanolic extract of $C$. aromaticus leaves when compared with the negative control. Similarly according to the TLC-bioassay done by Bandara et al., (1987), steam distillates of the leaves of $C$. aromaticus and $C$. lacciferus have displayed a considerable antifungal activity against Cladosporium cladosporioides. The active compound 2,6-dimethoxybenzoquinone isolated from the chloroform extract of $C$. lacciferus roots have exhibited antifungal activity against the growth of plant pathogenic fungi such as Botrydiplodia theobromae, C. gloeosporioides and Gibberella fujikuroi and two saprophytic fungi such as Aspergillus niger and C. cladosporioides. Moreover, petroleum and chloroform extracts of Croton officinalis roots have displayed antifungal properties against $C$. cladosporioides (Bandara et al., 1987). Further, essential oils of several Croton species (Fontenelle et al., 2007) and methanolic and aqueous extracts of Croton macrostachyus (Teugwa et al., 2013) have demonstrated antifungal activity against several human pathogenic fungi. Growth of C. gleosporioides has been greatly inhibited by numerous other plant extracts such as ethyl acetate extract of Lantana camara with inhibition zone of $35.3 \mathrm{~mm}$ (Adme et al., 2013), aqueous extract of papaya leaves with $12 \%$ of mycelial growth inhibition (Abirami et al., 2013) and ethanolic, petroleum ether and chloroform extracts of stems of Avicennia schaueriana by agar dilution assay (Fardin and Young, 2015). Significant inhibition (88\%) of the growth of $P$. mangiferae has been reported by Rai, (1996) with Eucalyptus globulus and Catharanthus roseus. Inhibition of mycelial growth of $L$. theobromae could not be achieved by $C$. aromaticus leaf extract during the present study. However, mycelial growth 
of L. theobromae isolated from banana has (2004) reported that cinnamon bark, leaf and previously been inhibited by garlic clove and clove oils are fungicidal against $L$. theobromae cinnamon leaf extracts by 47.09 and $33.86 \%$, isolated from banana.

respectively (Nath et al., 2014). Anthony et al.,

Table 01: Antifungal activity of ethanolic extract of Croton aromaticus and Captan against mycelial growth of post harvest fungal pathogens.

\begin{tabular}{|c|c|c|c|}
\hline \multirow{2}{*}{ Fungus } & \multirow{2}{*}{$\begin{array}{l}\text { Concentration } \\
\left(\mathrm{mg} \mathrm{ml}^{-1}\right)\end{array}$} & \multicolumn{2}{|c|}{ Diameter of inhibition zones $(\mathrm{cm})$} \\
\hline & & Extract & Captan (Positive Control) \\
\hline \multirow{9}{*}{$\begin{array}{l}\text { C. musae } \\
\text { (Banana) }\end{array}$} & 0 (Negative Control) & $0.7 \pm 0.0^{\mathrm{d} *}$ & \\
\hline & 1 & $0.7 \pm 0.0^{\mathrm{d}}$ & $0.7 \pm 0.0^{\mathrm{g}}$ \\
\hline & 5 & $0.7 \pm 0.0^{\mathrm{d}}$ & $0.7 \pm 0.0^{\mathrm{g}}$ \\
\hline & 10 & $0.7 \pm 0.0^{\mathrm{d}}$ & $1.4 \pm 0.0^{\mathrm{f}}$ \\
\hline & 30 & $1.3 \pm 0.1^{\mathrm{c}}$ & $1.6 \pm 0.1^{\mathrm{e}}$ \\
\hline & 50 & $1.6 \pm 0.0^{\mathrm{b}}$ & $1.9 \pm 0.1^{\mathrm{d}}$ \\
\hline & 100 & $1.8 \pm 0.1^{\mathrm{a}}$ & $2.0 \pm 0.0^{\text {cd }}$ \\
\hline & 200 & $1.5 \pm 0.0^{\mathrm{b}}$ & $2.1 \pm 0.0^{\mathrm{bc}}$ \\
\hline & 300 & $1.2 \pm 0.1^{\mathrm{c}}$ & $2.3 \pm 0.1^{\mathrm{b}}$ \\
\hline \multirow{9}{*}{$\begin{array}{l}\text { L. theobromae } \\
\text { (Banana) }\end{array}$} & 0 (Negative Control) & $0.7 \pm 0.0^{\mathrm{a}}$ & \\
\hline & 1 & $0.7 \pm 0.0^{\mathrm{a}}$ & $0.7 \pm 0.0^{\mathrm{a}}$ \\
\hline & 5 & $0.7 \pm 0.0^{\mathrm{a}}$ & $0.7 \pm 0.0^{\mathrm{a}}$ \\
\hline & 10 & $0.7 \pm 0.0^{\mathrm{a}}$ & $0.7 \pm 0.0^{\mathrm{a}}$ \\
\hline & 30 & $0.7 \pm 0.0^{\mathrm{a}}$ & $0.7 \pm 0.0^{\mathrm{a}}$ \\
\hline & 50 & $0.7 \pm 0.0^{\mathrm{a}}$ & $0.7 \pm 0.0^{\mathrm{a}}$ \\
\hline & 100 & $0.7 \pm 0.0^{\mathrm{a}}$ & $0.7 \pm 0.0^{\mathrm{a}}$ \\
\hline & 200 & $0.7 \pm 0.0^{\mathrm{a}}$ & $0.7 \pm 0.0^{\mathrm{a}}$ \\
\hline & 300 & $0.7 \pm 0.0^{\mathrm{a}}$ & $0.7 \pm 0.0^{\mathrm{a}}$ \\
\hline \multirow{9}{*}{$\begin{array}{l}\text { A. alternata } \\
\text { (Mango) }\end{array}$} & 0 (Negative Control) & $0.7 \pm 0.0^{\circ}$ & \\
\hline & 1 & $0.7 \pm 0.0^{\mathrm{c}}$ & $0.7 \pm 0.0^{\mathrm{e}}$ \\
\hline & 5 & $0.7 \pm 0.0^{\mathrm{e}}$ & $1.3 \pm 0.0^{\mathrm{d}}$ \\
\hline & 10 & $1.1 \pm 0.0^{\mathrm{d}}$ & $1.5 \pm 0.1^{\mathrm{c}}$ \\
\hline & 30 & $1.3 \pm 0.1^{\mathrm{c}}$ & $1.6 \pm 0.0^{\mathrm{c}}$ \\
\hline & 50 & $1.9 \pm 0.0^{\mathrm{b}}$ & $2.1 \pm 0.1^{\mathrm{b}}$ \\
\hline & 100 & $2.2 \pm 0.1^{\mathrm{a}}$ & $2.5 \pm 0.0^{\mathrm{a}}$ \\
\hline & 200 & $1.7 \pm 0.1^{\mathrm{f}}$ & $2.4 \pm 0.1^{\mathrm{a}}$ \\
\hline & 300 & $0.7 \pm 0.0^{\mathrm{c}}$ & $2.5 \pm 0.1^{\mathrm{a}}$ \\
\hline \multirow{9}{*}{$\begin{array}{l}\text { P. mangiferae } \\
\text { (Mango) }\end{array}$} & 0 (Negative Control) & $0.7 \pm 0.0^{\mathrm{d}}$ & \\
\hline & 1 & $0.7 \pm 0.0^{\mathrm{d}}$ & $1.6 \pm 0.0^{\mathrm{f}}$ \\
\hline & 5 & $1.1 \pm 0.1^{\mathrm{c}}$ & $1.9 \pm 0.0^{\mathrm{e}}$ \\
\hline & 10 & $1.3 \pm 0.1^{\mathrm{bc}}$ & $2.1 \pm 0.0^{\mathrm{e}}$ \\
\hline & 30 & $1.5 \pm 0.0^{\mathrm{b}}$ & $2.3 \pm 0.0^{\mathrm{d}}$ \\
\hline & 50 & $1.8 \pm 0.0^{\mathrm{a}}$ & $2.4 \pm 0.0^{\mathrm{cd}}$ \\
\hline & 100 & $2.1 \pm 0.0^{\mathrm{a}}$ & $2.6 \pm 0.0^{\mathrm{bc}}$ \\
\hline & 200 & $2.0 \pm 0.1^{\mathrm{a}}$ & $2.7 \pm 0.1^{\mathrm{ab}}$ \\
\hline & 300 & $0.7 \pm 0.0^{\mathrm{d}}$ & $2.9 \pm 0.0^{\mathrm{a}}$ \\
\hline
\end{tabular}




\begin{tabular}{|c|c|c|c|}
\hline \multirow{2}{*}{ Fungus } & \multirow{2}{*}{$\begin{array}{l}\text { Concentration } \\
\left(\mathrm{mg} \mathrm{ml}^{-1}\right)\end{array}$} & \multicolumn{2}{|c|}{ Diameter of inhibition zones $(\mathrm{cm})$} \\
\hline & & Extract & Captan (Positive Control) \\
\hline \multirow{9}{*}{$\begin{array}{l}\text { L. theobromae } \\
\text { (Mango) }\end{array}$} & 0 (Negative Control) & $0.7 \pm 0.0^{\mathrm{a}}$ & \\
\hline & 1 & $0.7 \pm 0.0^{\mathrm{a}}$ & $0.7 \pm 0.0^{c}$ \\
\hline & 5 & $0.7 \pm 0.0^{\mathrm{a}}$ & $0.7 \pm 0.0^{c}$ \\
\hline & 10 & $0.7 \pm 0.0^{\mathrm{a}}$ & $0.7 \pm 0.0^{\mathrm{c}}$ \\
\hline & 30 & $0.7 \pm 0.0^{\mathrm{a}}$ & $0.7 \pm 0.0^{\mathrm{c}}$ \\
\hline & 50 & $0.7 \pm 0.0^{\mathrm{a}}$ & $0.7 \pm 0.0^{c}$ \\
\hline & 100 & $0.7 \pm 0.0^{\mathrm{a}}$ & $1.1 \pm 0.1^{\mathrm{b}}$ \\
\hline & 200 & $0.7 \pm 0.0^{\mathrm{a}}$ & $1.3 \pm 0.0^{\mathrm{a}}$ \\
\hline & 300 & $0.7 \pm 0.0^{\mathrm{a}}$ & $1.4 \pm 0.0^{\mathrm{a}}$ \\
\hline \multirow{9}{*}{$\begin{array}{l}\text { L. theobromae } \\
\text { (Papaya) }\end{array}$} & 0 (Negative Control) & $0.7 \pm 0.0^{\mathrm{a}}$ & \\
\hline & 1 & $0.7 \pm 0.0^{\mathrm{a}}$ & $0.7 \pm 0.0^{\mathrm{e}}$ \\
\hline & 5 & $0.7 \pm 0.0^{\mathrm{a}}$ & $0.7 \pm 0.0^{\mathrm{e}}$ \\
\hline & 10 & $0.7 \pm 0.0^{\mathrm{a}}$ & $1.1 \pm 0.0^{\mathrm{cd}}$ \\
\hline & 30 & $0.7 \pm 0.0^{\mathrm{a}}$ & $1.0 \pm 0.0^{\mathrm{d}}$ \\
\hline & 50 & $0.7 \pm 0.0^{\mathrm{a}}$ & $1.2 \pm 0.0^{\mathrm{bc}}$ \\
\hline & 100 & $0.7 \pm 0.0^{\mathrm{a}}$ & $1.4 \pm 0.0^{\mathrm{ab}}$ \\
\hline & 200 & $0.7 \pm 0.0^{\mathrm{a}}$ & $1.6 \pm 0.0^{\mathrm{a}}$ \\
\hline & 300 & $0.7 \pm 0.0^{\mathrm{a}}$ & $1.6 \pm 0.0^{\mathrm{a}}$ \\
\hline \multirow{9}{*}{$\begin{array}{l}\text { C. gleosporiodes } \\
\text { (Papaya) }\end{array}$} & 0 (Negative Control) & $0.7 \pm 0.0^{\mathrm{e}}$ & \\
\hline & 1 & $0.7 \pm 0.0^{\mathrm{e}}$ & $1.5 \pm 0.0^{\mathrm{e}}$ \\
\hline & 5 & $1.2 \pm 0.0^{\mathrm{d}}$ & $1.8 \pm 0.1^{\mathrm{de}}$ \\
\hline & 10 & $1.4 \pm 0.0^{c}$ & $1.9 \pm 0.0^{\mathrm{cd}}$ \\
\hline & 30 & $1.5 \pm 0.0^{c}$ & $2.2 \pm 0.0^{\mathrm{bc}}$ \\
\hline & 50 & $1.7 \pm 0.1^{\mathrm{b}}$ & $2.4 \pm 0.1^{\mathrm{ab}}$ \\
\hline & 100 & $2.0 \pm 0.0^{\mathrm{a}}$ & $2.5 \pm 0.1^{\mathrm{a}}$ \\
\hline & 200 & $1.8 \pm 0.0^{\mathrm{b}}$ & $2.6 \pm 0.1^{\mathrm{a}}$ \\
\hline & 300 & $0.7 \pm 0.0^{\mathrm{c}}$ & $2.6 \pm 0.1^{\mathrm{a}}$ \\
\hline
\end{tabular}

Each data value represents the mean of 12 replicates \pm standard error. Mean values sharing common letters in each column of each fungus are not significantly different $(\mathrm{P}>0.05)$

*Well diameter is $0.7 \mathrm{~cm}$, and this value indicates absence of inhibition zone.

When considering both mycelial growth and spore germination, the highest inhibitions of all tested fungi were observed at $100 \mathrm{mg} \mathrm{ml}^{-}$ 1. A. alternata showed the highest inhibition of mycelia growth $(2.2 \mathrm{~cm})$ and the highest inhibition of spore germination $(2.2 \mathrm{~cm})$ (Figure 01) was observed for C. musae at 100 $\mathrm{mg} \mathrm{ml}^{-1}$. Similarly, C. musae has been greatly inhibited by methanolic leaf extract of Prosopis juliflora with highest inhibition zone of mycelial growth being $30.7 \mathrm{~mm}$ and inhibition of spore germination being up to $0.3 \%$ (Bazie et al., 2014). However, another study reported that spore germination of Alternaria sp. is stimulated by $C$. papaya latex (Indrakeerthi and Adikaram, 2011).
The results obtained from the present study showed no inhibitory effects when DMSO (negative control) was evaluated against test fungi. Inhibition of both mycelial growth and spore germination of test fungi by Captan was increased with increasing concentration. The mean diameter of zones of inhibition increased up to a certain level and then decreased when the concentration of the plant extract increased. There was no significant inhibition of mycelial growth and spore germination of most of the test fungi at $300 \mathrm{mg} \mathrm{ml}^{-1}$ of $C$. aromaticus leaf extract. This reduction of inhibition with increasing concentration may be due to the low diffusion of the ethanolic extract through the agar medium at high concentrations, as ethanol extractions resulted in a thicker liquid. 
Table 02: Antifungal activity of ethanolic extract of Croton aromaticus and Captan against spore germination of post harvest fungal pathogens.

\begin{tabular}{|c|c|c|c|}
\hline \multirow{2}{*}{ Fungus } & \multirow{2}{*}{$\begin{array}{l}\text { Concentration } \\
\left(\mathrm{mg} \mathrm{ml}^{-1}\right)\end{array}$} & \multicolumn{2}{|c|}{ Diameter of inhibition zones $(\mathrm{cm})$} \\
\hline & & Extract & Captan (Positive Control) \\
\hline C. musae & 0 (Negative Control) & $0.7 \pm 0.0^{\mathrm{e} *}$ & \\
\hline \multirow[t]{8}{*}{ (Banana) } & 1 & $0.7 \pm 0.0^{\mathrm{e}}$ & $0.7 \pm 0.0^{\mathrm{f}}$ \\
\hline & 5 & $0.7 \pm 0.0^{\mathrm{e}}$ & $1.4 \pm 0.0^{\mathrm{e}}$ \\
\hline & 10 & $1.2 \pm 0.1^{\mathrm{d}}$ & $1.5 \pm 0.0^{\mathrm{e}}$ \\
\hline & 30 & $1.4 \pm 0.0^{\mathrm{d}}$ & $1.7 \pm 0.1^{\mathrm{d}}$ \\
\hline & 50 & $1.8 \pm 0.0^{\mathrm{b}}$ & $2.1 \pm 0.0^{c}$ \\
\hline & 100 & $2.2 \pm 0.1^{\mathrm{a}}$ & $2.4 \pm 0.1^{\mathrm{b}}$ \\
\hline & 200 & $1.6 \pm 0.1^{\mathrm{c}}$ & $2.5 \pm 0.0^{\mathrm{b}}$ \\
\hline & 300 & $0.7 \pm 0.0^{\mathrm{e}}$ & $2.7 \pm 0.0^{\mathrm{a}}$ \\
\hline A. alternata & 0 (Negative Control) & $0.7 \pm 0.0^{\mathrm{a}}$ & \\
\hline \multirow{8}{*}{ (Mango) } & 1 & $0.7 \pm 0.0^{\mathrm{a}}$ & $0.7 \pm 0.0^{\mathrm{g}}$ \\
\hline & 5 & $0.7 \pm 0.0^{\mathrm{a}}$ & $1.2 \pm 0.0^{\mathrm{f}}$ \\
\hline & 10 & $0.7 \pm 0.0^{\mathrm{a}}$ & $1.3 \pm 0.0^{\mathrm{f}}$ \\
\hline & 30 & $1.3 \pm 0.1^{\mathrm{c}}$ & $1.5 \pm 0.0^{\mathrm{e}}$ \\
\hline & 50 & $1.5 \pm 0.1^{\mathrm{b}}$ & $1.7 \pm 0.1^{\mathrm{d}}$ \\
\hline & 100 & $2.0 \pm 0.1^{\mathrm{a}}$ & $2.2 \pm 0.1^{\mathrm{c}}$ \\
\hline & 200 & $1.6 \pm 0.1^{\mathrm{b}}$ & $2.4 \pm 0.0^{\mathrm{b}}$ \\
\hline & 300 & $0.7 \pm 0.0^{\mathrm{a}}$ & $2.6 \pm 0.0^{\mathrm{ab}}$ \\
\hline P. mangiferae & 0 (Negative Control) & $0.7 \pm 0.0^{\mathrm{e}}$ & \\
\hline \multirow{8}{*}{ (Mango) } & 1 & $0.7 \pm 0.0^{\mathrm{e}}$ & $1.5 \pm 0.0^{\mathrm{f}}$ \\
\hline & 5 & $1.0 \pm 0.0^{\mathrm{d}}$ & $1.8 \pm 0.0^{\mathrm{e}}$ \\
\hline & 10 & $1.2 \pm 0.0^{\mathrm{c}}$ & $1.9 \pm 0.0^{\mathrm{c}}$ \\
\hline & 30 & $1.5 \pm 0.0^{\mathrm{b}}$ & $2.1 \pm 0.0^{\mathrm{d}}$ \\
\hline & 50 & $1.6 \pm 0.0^{\mathrm{b}}$ & $2.2 \pm 0.0^{\text {cd }}$ \\
\hline & 100 & $1.9 \pm 0.0^{\mathrm{a}}$ & $2.4 \pm 0.0^{\mathrm{bc}}$ \\
\hline & 200 & $1.5 \pm 0.0^{\mathrm{b}}$ & $2.5 \pm 0.0^{\mathrm{b}}$ \\
\hline & 300 & $0.7 \pm 0.0^{\mathrm{e}}$ & $2.8 \pm 0.0^{\mathrm{a}}$ \\
\hline C. gleosporiodes & 0 (Negative Control) & $0.7 \pm 0.0^{\mathrm{e}}$ & \\
\hline \multirow{8}{*}{ (Papaya) } & 1 & $0.7 \pm 0.0^{\mathrm{e}}$ & $1.4 \pm 0.1^{\mathrm{d}}$ \\
\hline & 5 & $1.1 \pm 0.0^{\mathrm{d}}$ & $1.5 \pm 0.1^{\mathrm{cd}}$ \\
\hline & 10 & $1.3 \pm 0.0^{\mathrm{c}}$ & $1.7 \pm 0.1^{\mathrm{c}}$ \\
\hline & 30 & $1.4 \pm 0.1^{\mathrm{bc}}$ & $2.0 \pm 0.0^{\mathrm{b}}$ \\
\hline & 50 & $1.6 \pm 0.1^{\mathrm{a}}$ & $2.1 \pm 0.1^{\mathrm{b}}$ \\
\hline & 100 & $1.8 \pm 0.0^{\mathrm{a}}$ & $2.2 \pm 0.1^{\mathrm{ab}}$ \\
\hline & 200 & $1.5 \pm 0.0^{\mathrm{b}}$ & $2.4 \pm 0.0^{\mathrm{a}}$ \\
\hline & 300 & $0.7 \pm 0.0^{\mathrm{e}}$ & $2.4 \pm 0.0^{\mathrm{a}}$ \\
\hline
\end{tabular}

Each data value represents the mean of 12 replicates \pm standard error. Mean values sharing common letters in each column of each fungus are not significantly different $(\mathrm{P}>0.05)$

*Well diameter is $0.7 \mathrm{~cm}$, and this value indicates absence of inhibition zone. 

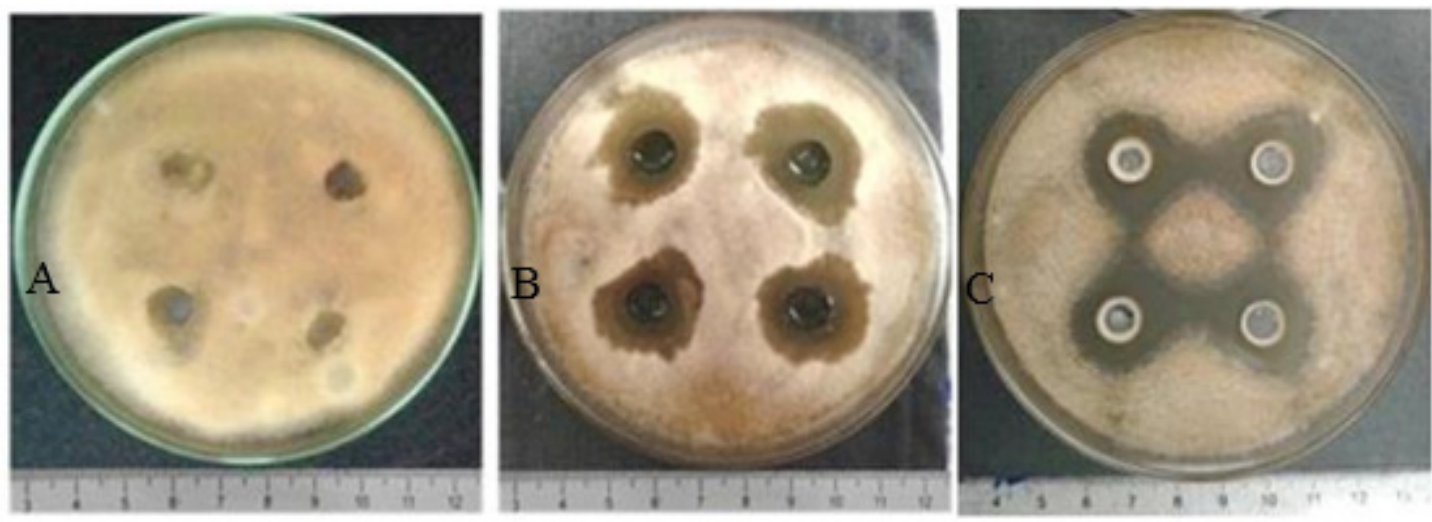

Figure 01: Inhibition zones produced by the standard fungicide, captan and the ethanolic extract of $C$. aromaticus leaves on $C$. musae on PDA, (A) Negative control (DMSO); (B) Zones of inhibition from $100 \mathrm{mg} \mathrm{ml}^{-1}$ of ethanolic leaf extract; (C) Zones of inhibition from $300 \mathrm{mg}$ $\mathrm{ml}^{-1}$ of Captan.

It showed significantly higher inhibition of both mycelial growth and spore germination of C. musae, A. alternata, C. gleosporioides, $P$. mangiferae and inhibition of mycelial growth of $L$. theobromae isolated from mango and papaya by Captan, when compared with the leaf extract. However, there was no significant difference of spore germination inhibition of $C$. musae at $100 \mathrm{mg} \mathrm{ml}^{-1}$ by Captan and the extract. Furthermore, both Captan and the leaf extract were unable to inhibit the mycelia growth of L. theobromae isolated from banana. Mycelial growth of $L$. theobromae isolated from mango and papaya were inhibited by Captan by $100 \mathrm{mg}$ $\mathrm{ml}^{-1}$ and $10 \mathrm{mg} \mathrm{ml}^{-1}$ respectively while the leaf extract was unable to show zones of inhibition at any of test concentrations.

Results revealed that mycelial growth of C. musae and A. alternata was inhibited by ethanolic leaf extract of $C$. aromaticus at minimum inhibitory concentration (MIC) of 30 $\mathrm{mg} \mathrm{ml}^{-1}$ and $10 \mathrm{mg} \mathrm{ml}^{-1}$ respectively. The MIC value of the leaf extract on mycelial growth and spore germination of $C$. gleosporioides and $P$. mangiferae was $5 \mathrm{mg} \mathrm{ml}^{-1}$. MIC value of leaf extract on spore germination of $C$. musae and A. alternata was observed at $10 \mathrm{mg} \mathrm{ml}^{-1}$ and 30

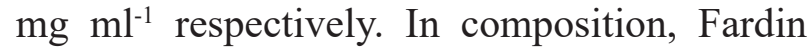
and Young (2015) have reported that MIC of ethanolic extract of Avicennia schaueriana leaves on growth of $C$. gloeopsporioides is more than $5 \mathrm{mg} \mathrm{ml}^{-1}$ by agar dilution assay.

\section{Phytochemical screening}

Different components in the plant extracts can be identified by using various analytical techniques such as Nuclear Magnetic Resonance (NMR) spectroscopy, high performance liquid chromatography (HPLC) etc. However, in the present study an attempt was made to conduct a preliminary phytochemical analysis, as chemotaxonomic studies of Croton species have been previously carried out by Bandara et al., (1988). TLC analysis of the present study revealed the presence of four active components (One grayish green colour spot, two gray colour spots and one yellow colour spot) with Rf values of, $0.551,0.672,0.810$ and 0.913 when observed under visible light. However, no UV active compounds were detected. According to Bandara et al., (1987) steam distillates of the leaves of $C$. aromaticus have displayed three antifungal compounds against C. cladosporioides with $\mathrm{Rf}$ values of $0.2,0.4$ and 0.6 on a TLC plate which was developed in chloroform. Further, Bandara et al., (1988) reported the presence of a grayish blue spot corresponding to (-)- hardwickiic acid and yellow colour spot corresponding to flavones on TLC with the petroleum and chloroform 
extracts of C. aromaticus roots and methanolic extract of $C$. lacciferus leaves, respectively (after developing plates in chloroform).

Many plants have the ability to synthesize secondary metabolites, like phenols, terpinoids, glycosides, steroids, quinones, flavonoids, tannins and coumarins, which have toxic effects on microorganisms causing plant diseases (Enyiukwu et al., 2013). Current qualitative analysis of ethanolic extract of $C$. aromaticus leaves indicated the presence of alkaloids, terpinoids, quinones, steroids and flavonoids, but not phenol, tannin and saponins. Bandara et al., (1990) reported that roots of $C$. aromaticus yield $\beta$ amyrin and (-)- hardwickiic acid and sesquiterpinoids as major secondary metabolites. Teugwa et al., (2013) indicated that methanolic extract of C. macrostachyus consist of phenolic compound, tannins, alkaloids and anthraquinons that are thought to display antifungal activity against human pathogens.

Findings of the present study clearly indicates the possibility of suppressing the growth of postharvest fungal pathogens, C. musae, $C$. gleosporioides, A. alternata and P. mangiferae using ethanolic extract of $C$. aromaticus leaves in agar well diffusion assay. Although the ethanolic extract of $C$. aromaticus leaf extract shows antifungal activity on postharvest fungal pathogens in vitro, in vivo testing of the $C$. aromaticus leaf extract on banana, papaya and mango fruits is needed to demonstrate the in vivo efficacy of ethanolic extract of $C$. aromaticus leaves and its persistence, safety and commercial feasibility, before application for postharvest disease control. Therefore, this research opens an avenue for further studies on use of bioactive compounds of ethanolic extract of $C$. aromaticus leaves to control postharvest fungal pathogens.

\section{CONCLUSIONS}

According to this study, ethanolic leaf extract of $C$. aromaticus significantly inhibited the mycelial growth and spore germination of postharvest fungal pathogens (C. musae, $A$. alternata, $P$. mangiferae and $C$. gleosporioides) which were isolated from banana, papaya and mango. Ethanolic extract of $C$. aromaticus leaves contain compounds such as alkaloids, terpenoids, quinones, steroids and flavonoids which may be responsible for antifungal activity. The results support the idea that $C$. aromaticus plant extracts could be a promising source of potential antifungal agents to control post harvest diseases of fruits.

\section{ACKNOWLEDGEMENTS}

Financial assistance provided by University of Kelaniya (grant RP/03/02/01/01/2015) is highly appreciated. The authors thank Prof. (Mrs.) R.A.S.P. Senanayake, Head of the Department of Botany, University of Kelaniya, for providing facilities to conduct this research.

\section{REFERENCES}

Abeywickrama, K. (2006). A pictorial guide to rapid and accurate identification of postharvest diseases of fruits. $1^{\text {st }}$ Edition. Godage International Publishers, Colombo, Sri Lanka. pp. 1756.

Abeywickrama, K., Wijerathna, C., Rajapaksha, N., Sarananda, K. and Kannangara, S. (2012). Disease control strategies for extending storage life of papaya (Carica papaya), cultivars 'Red Lady' and 'Rathna', Ceylon Journal of Science. 41(1): postharvest diseases 27-34. http://dx.doi.org/10.4038/cjsbs.v41i1.4535 
Abirami, L., Pushkala, R. and Srividya, N. (2013). Antimicrobial activity of selected plant extracts against two important fungal pathogens isolated from papaya fruit, International Journal of Research in Pharmaceutical and Biomedical Sciences. 4(1): pp. 234-238.

Adme, A., Ayalew, A. and Woldestsadik, K. (2013). Evaluation of antifungal activity of plant extracts against papaya anthracnose (Colletotrichum gloeosporioides), Journal of Plant Pathology and Microbiology. 4: pp. 1-4. http://dx.doi.org/10.4172/2157-7471.1000207

Amjad, L., Mousavidehmourdi, K. and Saghazadeh, M. (2012). Antifungal potential of Achillea wilhelmsii flowers methanolic extract on different strains of Candida albicans, International Journal of Biological \& Medical Research. 3(3): pp. 2107-2110.

Anthony, S., Abeywickrama, K., Arambewela, L., Dayananda, R. and Wijeratnam, S. W. (2004). Fungal pathogens associated with banana fruit in Sri Lanka, and their treatment with essential oils, Mycopathologia. 157: pp. 91-97. http://dx.doi.org/10.1023/ B:MYCO.0000012226.95628.99 PMid:15008351

Bandara, B.M.R., Wimalasiri, W.R., Adikaram, N.K.B. and Balasubramanlam, S. (1987). Antifungal properties of Croton aromaticus, C. lacciferus and C. officinalis including the isolation of a fungicidal constituent, Journal of National Science Council of Sri Lanka. 20: pp. 11-17.

Bandara, B.M.R., Wimalasiri, W.R. and Balasubramanium, S. (1988). Chemotaxonomic studies of Croton species of Sri Lanka, Journal of National Science Council of Sri Lanka. 16(1): pp. 87-95.

Bandara, B.M.R., Wimalasiri, W.R., Wickremasinghe, W. A., Bandara, K.A.N.P. (1990). Cyperenoic acid and (-)- Hardwickiic acid from the chloroform extract of the roots of Croton aromaticus: isolation and insecticidal properties, Journal of National Science Council of Sri Lanka. 18(2): pp. 119-126.

Bazie, S., Ayalew, A. and Woldetsadik, K. (2014). Antifungal activity of some plant extracts against (Colletotrichum Musae) the cause of postharvest banana anthracnose, Journal of Plant Pathology and Microbiology. 5: pp. 226.

Britto, A.J.D., Sebestian, S.R. and Sujin, R.M. (2012). Antibacterial activity of selected species of Lamiaceae against human pathogens, Indian Journal of Natural Product and Resources. 3(3): pp. 334-342.

Bussaman, P., Namsena, P., Rattanasena, P. and Chandrapatya, A. (2012). Effect of crude leaf extracts on Colletotrichum gloeosporioides (Penz.) Sacc, Psyche. 2012: pp. 1-6. http:// dx.doi.org/10.1155/2012/309046

Enyiukwu, D.N., Awurum, A.N., Ononuju, C.C. and Nwaneri, J.A. (2013). Significance of characterization of secondary metabolites from extracts of higher plants in plant disease management, International Journal of Advance Agricultural Research. 2: pp. 8-28.

Fardin, K.M. and Young, M.C.M. (2015). Antifungal potential of Avicennia schaueriana Stapf \& Leech. (Acanthaceae) against Cladosporium and Colletotrichum species, Letters in Applied Microbiology. 61: pp. 50-57. http://dx.doi.org/10.1111/lam.12423 PMid:25825048 
Felgel, T.W. (1980). Semi permanent microscope slides of micro fungi using sticky tape technique, Canadian Journal of Microbiology. 26: pp. 551-553. http://dx.doi.org/10.1139/m80-095

Fernandes, H.M.B., Leao, A.D., Oliveira-Filho, A.A., Sousa, J.P., Oliveira, T.L., Lima, E.O., Silva, M.S. and Tavares, J.F. (2013). Antimicrobial activity and phytochemical screening of extracts from leaves of Croton polyandrus Spreng, International Journal of Pharmacognosy and Phytochemical Research. 5(3): pp. 223-226.

Fontenelle, R.O.S., Morais, S.M., Brito, E.H.S., Brilhante, R.S.N., Cordeiro, R.A., Nascimento, N.R.F., Kerntopf, M.R., Sidrim, J.J.C. and Rocha, M.F.G. (2007). Antifungal activity of essential oils of Croton species from the Brazilian Caatinga biome, Journal of Applied Microbiology. 104(2008): pp. 1383-1390.

Indrakeerthi, S.R.P. and Adikaram, N.K.B. (2011). Control of crown rot of banana using Carica papaya latex, Journal of .National .Science.Foundation Sri Lanka. 39 (2): pp. 155-162.

Jayaweera, D.M.A. and Senaratna, L.I.K. (2006). Medicinal plants (Indigenous and Exotic) used in Ceylon. $3^{\text {rd }}$ Edition. The National Science Foundation, Sri Lanka. pp. 197.

Mansour, F.S., Abd-El-Aziz, S.A. and Helal, G.A. (2006). Effect of fruit heat treatment in three mango varieties on incidence of postharvest fungal disease, Journal of Plant Pathology. 88 (2): pp. 141-148.

Mari, M., Francesco, A.D. and Bertolini, P. (2014). Control of fruit postharvest diseases: old issues and innovative approaches, Stewart Postharvest Review. 1(1): pp. 1-4. http://dx.doi. org/10.2212/spr.2014.1.1

Meer, H., Iram, S., Ahmad, I., Fateh, F.S. and Kazmi, M.R. (2013). Identification and characterization of post harvest fungal pathogens of mango from domestic markets of Punjab, International Journal of Agronomy and Plant Production. 4 (4): pp. 650-658.

Nath, K., Solanky, K.U. and Kumawat, G.L. (2014). Effective Approaches of Potential Bioagent, Phytoextract, Fungicide and Cultural Practice for Management of Banana Fruit Rot Disease, Journal of Plant Pathology and Microbiology. 5: pp. 246.

Paranagama, P., Adhikari, C., Abeywickrama, K. and Bandara, P. (2003). Deterrent effects of some Sri Lankan essential oils on oviposition and progeny production of the cowpea bruchid, Callosobruchus maculatus (F.) (Coleoptera; Bruchidae), Food, Agriculture \& Environment. 1(2): pp. 254-257.

Paranagama, P.A., Wijeratne, E.M.K., Burns, A.M., Marron, M.T., Gunatilaka, M.K., Arnold, A.E. and Gunatilaka, A.A.L. (2007). Heptaketides from Corynespora sp. inhabiting the Cavern Beard Lichen, Usnea cawernosa: First report of metabolites of an Endolichenic fungus, Journal of natural products. 70: 1700-1705. http://dx.doi.org/10.1021/np070466w PMid:17988097

Rai, M.K. (1996). In vitro evaluation of medicinal plant extracts against Pestalotiopsis mangiferae, Hindustan Antibiotics Bulletin. 38(1-4): pp. 53-56. 
Rajan, M., Kumar, V.K., Kumar, P.S., Venkatachalam, T. and Anbarasan, V. (2011). Pharmacognostical and phytochemical studies of the leaves of Albizia Odoratissima (L.F) Benth, International Journal of Pharmacognosy and Phytochemical Research. 3(3): pp. 4755.

Ranasinghe, L., Jayawardena, B. and Abeywickrama, K. (2002). Fungicidal activity of essential oils of Cinnamomum zeylanicum (L.) and Syzygium aromaticum (L.) against crown rot and anthracnose pathogens isolated from banana, Letters in Applied Microbiology. 35: pp. 208211. http://dx.doi.org/10.1046/j.1472-765X.2002.01165.x PMid:12180942

Ranasinghe, L.S., Jayawardena, B. and Abeywickrama, K. (2003). Use of waste generated from cinnamon bark oil (Cinnamomum zeylanicum Blume) extraction as a post harvest treatment for Embul banana, Food, Agriculture \& Environment. 1(2): pp. 340-344.

Salatino, A., Salatino, M.L.F. and Negri, G. (2007). Traditional uses, Chemistry and Pharmacology of Croton species (Euphorbiaceae), Journal of the Brazilian Chemical Society. 18(1): pp. 1133. http://dx.doi.org/10.1590/S0103-50532007000100002

Singh, H., Al-samarai, G. and Syarhabil, M. (2012). Exploitation of natural products as an alternative strategy to control postharvest fungal rotting of citrus, International Journal of Scientific and Research Publications. 2(3): pp. 1-4. http://dx.doi.org/10.15373/22778179/ July2014/184

Singha, S., Banerjee, S. and Chandra, G. (2011). Synergistic effect of Croton caudatus (fruits) and Tiliacora acuminata (flowers) extracts against filarial vector Culex quinquefasciatus, Asian Pacific Journal of Tropical Biomedicine. pp. 159-164. http://dx.doi.org/10.1016/S22211691(11)60147-0

Teugwa, M. C., Sonfack, D.C. R., Fokom, R., Penlap, B. V. and Amvam, Z.P. H. (2013). Antifungal and antioxidant activity of crude extracts of three medicinal plants from Cameroon pharmacopea, Journal of Medicinal Plants Research. 7(21): pp. 1537-1542.

Ugochukwu, S.C., Arukwe, U.I. and Ifeanyi, O. (2013). Preliminary phytochemical screening of different solvent extracts of stem bark and roots of Dennetia tripetala G. Baker, Asian Journal of Plant Science and Research. 3(3): pp. 10-13.

Vishwakarma, S., Chandan, K., Jeba, R.C. and Khushbu, S. (2014). Comparative study of Qualitative Phytochemical screening and antioxidant activity of Mentha arvensis, Elettaria cardamomum and Allium porrum, Indo American Journal of Pharmaceutical Research. 4(5): pp. 2538- 2556. 